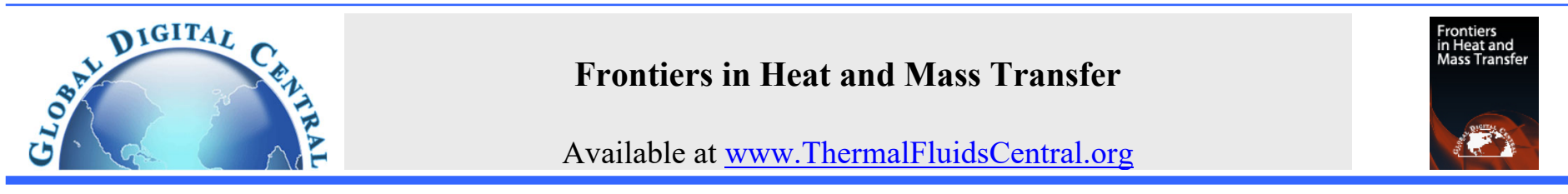

\title{
THERMAL ELECTRIC ANALYSIS OF 3-D SANDWICH COMPACT BUSBAR WITH CLASS-B AND CLASS-F INSULATION
}

\author{
B. Gangadhara Rao ${ }^{a,}{ }^{*}$ K. Elangovan ${ }^{b}$, K. Hema Chandra Reddy ${ }^{a}$, M. Arulprakasajothi ${ }^{c}$ \\ ${ }^{a}$ Department of Mechanical Engineering, JNTUA, Anantapur -515002, India. \\ ${ }^{\mathrm{b}}$ Department of Mechanical Engineering, Er. Perumal Manimekalai College of Engineering, Hosur, - 635117, India. \\ ${ }^{c}$ Department of Mechanical Engineering, Vel Tech Rangarajan Dr Sagunthala R\&D Institute of Science and Technology, Chennai, India
}

\begin{abstract}
In this research, the 3-D coupled thermal electric model analyses on a sandwich bus bar are presented for the comparison of F Class \& B Class of insulation. IEC defines the maximum temperature limit at the conductor based on the class of insulation. This paper gives the clarity on the variation on the current density i.e, the size of the conductor by varying the class of insulation. The study is conducted on tin plated $2000 \mathrm{~A}$ sandwich busbar system. The sandwich bus bar is made of copper conductors with tin plating and enclosed by an aluminum cover along its length. Numerous divisions of busbars are examined, to determine heat distribution through the three modes, i.e., conduction, convection and radiation. Evaluate the thermal endurance of B-class and F-class insulations of similar busbar geometry. The heat transfer coefficient is determined based on the fluctuating temperature and model geometry and is coupled with the finite element method. The solution of the temperature distribution due to applied current on the copper conductor are obtained in ANSYS 15.0. Investigation shows that, the vital temperature increment in conductor while changing the B-class insulation to $\mathrm{F}$ class and casing temperature remains without much of variation. By changing the class of insulation, it helps to raise the thermal endurance of the insulating busbar system. The tin plating in the bus duct system functions as the heat source or thermal sink and aids in the uniform distribution of heat energy along its length.
\end{abstract}

Keywords: Finite element methods, Thermal field, Coupled field, Busbar, Temperature rise, Heat transfer coefficient

\section{INTRODUCTION}

The arrangement of the busbar consists of electrically conducting strip of metal along with a neutral enclosed within a metal frame. The busbar is made using an electrically conductive metal or its alloy. Some busbars are coated with materials like copper, tin, and aluminium to increase its electrical conductivity (Mohan and Chatterjee, 2010; Xu et al., 2015). Typically, the geometrical configuration of the busbar is customized to enhance the electrical, mechanical and thermal properties of the busduct system and optimize its performance. This has led to the development of distinctive classes of busduct like phase isolated bus ducts and nonsegregated bus ducts (Ho et al., 2006).

Standards set by the International Electrotechnical Commission (IEC) are used as the reference while selecting and opting busducts for user specific applications. However, the standards do not mention the specifications for coating the busbar or provision of insulation on the busduct (Guzman et al. 2005). The electrician installing the busduct decides on the materials to be used for the insulation and adopts nonstandard coating on the busbar (Rosch, 1938; Viswanatha and Rakesh, 2016). To avoid complications during the usage of the busduct, dielectric, it is essential to characterize the thermal and circuit parameters (Heida et al., 1999; Tian and Zhao, 2019). The insulation given on the busbar helps to determine its characteristics for user specific applications (Anbo et al., 2002). Proper selection of the class as well as the type of the insulation coating can enhance the thermal distribution (Ohta, 1985; Poddar and Shashishekar, 2016; Manna and Oosthuizen, 2019). It can also increase the heat dissipation characteristics within the busbar enclosure (Wang and Guo, 2019; Kevin et al., 2019). The class of insulation generally used for the bus ducts can be widely defined as shown in Table 1.

Table 1 Class of insulation with operating temperature

\begin{tabular}{|c|c|}
\hline Temperature limit $\left({ }^{\mathbf{}} \mathbf{C}\right)$ & Class of insulation \\
\hline$<90$ & $\mathrm{Y}$ \\
\hline$<105$ & $\mathrm{~A}$ \\
\hline$<120$ & $\mathrm{E}$ \\
\hline$<130$ & $\mathrm{~B}$ \\
\hline$<155$ & $\mathrm{~F}$ \\
\hline$<180$ & $\mathrm{H}$ \\
\hline$>180$ & $\mathrm{C}$ \\
\hline
\end{tabular}

As per IEC 61439 the bus duct should be designed in such a way that the temperature rise at the conductor should equivalent or less that the permissible temperature limits of the insulating material in contact with the conductor. Thus, for an $\mathrm{F}$ class of insulation the conductor should be design with the temperature rise limit as $120^{\circ} \mathrm{C}$ with an average ambient temperature of $35^{\circ} \mathrm{C}$ so that the absolute temperature is lesser than the permissible limits of the insulation. In case of B class of insulation, the conductor should be design with the temperature rise limit as $95^{\circ} \mathrm{C}$ with an average ambient temperature of $35^{\circ} \mathrm{C}$ so that the absolute temperature is lesser than the permissible limits of the insulation.

In this study, busbar system coated with tin and enclosed in a metallic enclosure with class B and class F insulation is considered. These insulations are used in the operating range of 130 to $155^{\circ} \mathrm{C}$. Their

\footnotetext{
"Corresponding author. Email: ursganga@gmail.com
} 
electrical properties adhere to IEC standards. The busbar system is expected to give an optimal performance over a wide range of temperature. Background study is carried out to find the influence of the thermal performance of the tin coated busduct system as well as the characteristics of the enclosure and its joints

\section{METHODOLOGY}

\subsection{Geometrical Details of the Busbar and Insulations Classes}

A three-phase busbar system subjected to low voltage is analyzed in this paper. It is made up of three phase copper conductors along with the neutral in the busbar arrangement. Major dimensions of the studied two class of insulated busbar presented in Fig. 1.

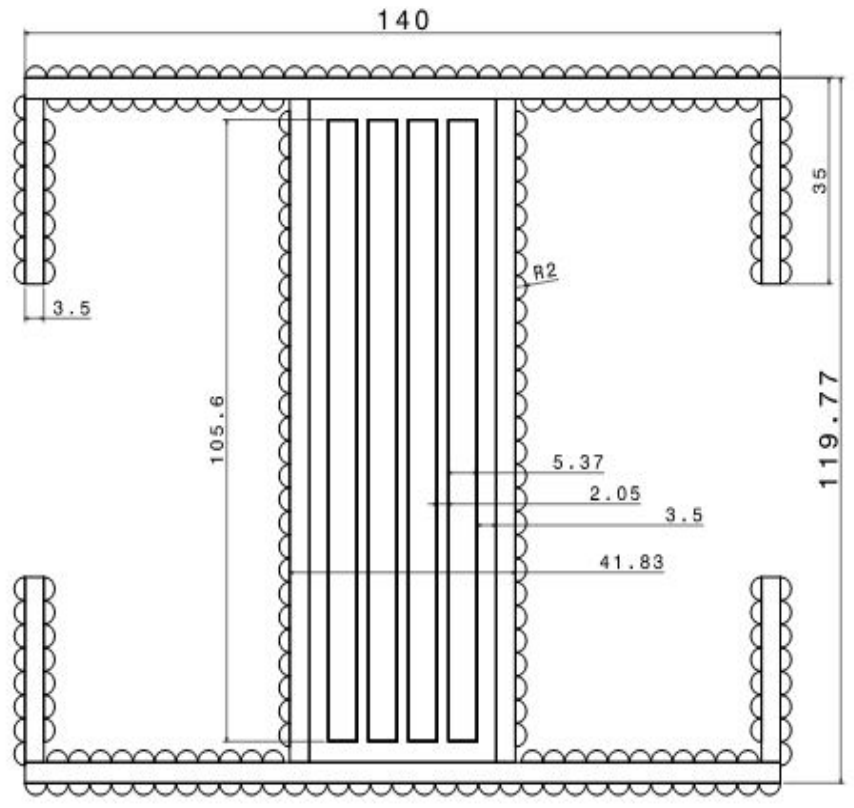

a. B-class insulation 140

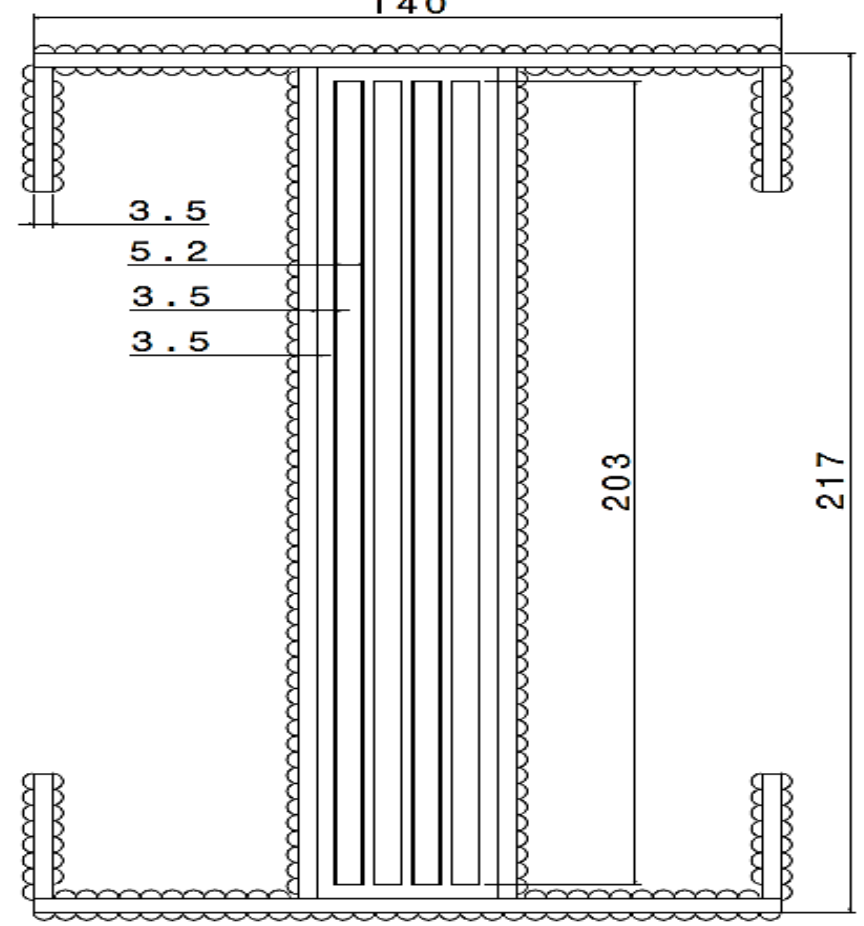

b. F-class insulation

Fig. 1 Illustration of the two different insulation classes in the busbar system
The electrical and mechanical performance of the busbar system is set to comply with the IEC 61439 standard (Ho et al., 2006). The study aims to control the temperature raise in the busbar system in comparison with the ambient conditions. The ambient temperature is assumed to be below $35^{\circ} \mathrm{C}$ during the test. The busbar system is considered to have natural convective heat transfer. In our case, for B-Class insulation the maximum temperature rise is $95^{\circ} \mathrm{C}$ on the conductor. The absolute temperature on the conductor including the ambient temperature is $130^{\circ} \mathrm{C}$ for copper busbar.

Table 2 Geometrical detail of B and F classes of insulation

\begin{tabular}{|l|l|l|}
\hline Parameter & $\begin{array}{l}\text { Values of B- } \\
\text { class insulation } \\
\text { with AL casing }\end{array}$ & $\begin{array}{l}\text { Values of F- } \\
\text { class insulation } \\
\text { with AL casing }\end{array}$ \\
\hline $\begin{array}{l}\text { RMS Values of current rating } \\
(\text { A) }\end{array}$ & 2000 & 2000 \\
\hline $\begin{array}{l}\text { Copper conductor Size (mm x } \\
\text { mm) }\end{array}$ & $5.37 \times 105.6$ & $5.2 \times 203$ \\
\hline $\begin{array}{l}\text { Spacing between the middle of } \\
\text { adjusting busbar }(\mathrm{mm})\end{array}$ & 2.05 & 2.05 \\
\hline Casing thickness $(\mathrm{mm})$ & 3.5 & 3.5 \\
\hline Fin Radius $(\mathrm{mm})$ & 2 & 2 \\
\hline $\begin{array}{l}\text { Busbar with Casing }(\mathrm{mm} x \\
\text { mm) }\end{array}$ & $140 \times 119.77$ & $140 \times 217$ \\
\hline Conductor Temperature $\left({ }^{\circ} \mathrm{C}\right)$ & 129.5 & 154.93 \\
\hline Casing Temperature $\left({ }^{\circ} \mathrm{C}\right)$ & 90 & 60.53 \\
\hline
\end{tabular}

In the case of the F-class insulation, the maximum temperature rise is $120^{\circ} \mathrm{C}$ on the conductor with an absolute temperature on the conductor including the ambient temperature as $155^{\circ} \mathrm{C}$ for copper busbar. In both the cases the other parameters like the geometry, ambient temperature of $35^{\circ} \mathrm{C}$ and the temperature rise limits at the enclosure as $55^{\circ} \mathrm{C}$ is remained same and are in-line with the standard of IEC. One side of the threephase busbar is connected with current sources and another side will be short circuit with the ground. The protective conductors is not connected to the power supply (Burali and Patil, 2014). Table 2 gives the details of the final design dimensions. Fig. 2 and Fig. 3 gives the final design geometry for the compact bus bars with B-class and F-class insulation respectively in accordance to the temperature rise limits of IEC. Table 3 gives the material properties of the various materials used for the compact bus bars. For B-class insulation Polypropylene was used. Similarly, for F-class Polyurethane was used.

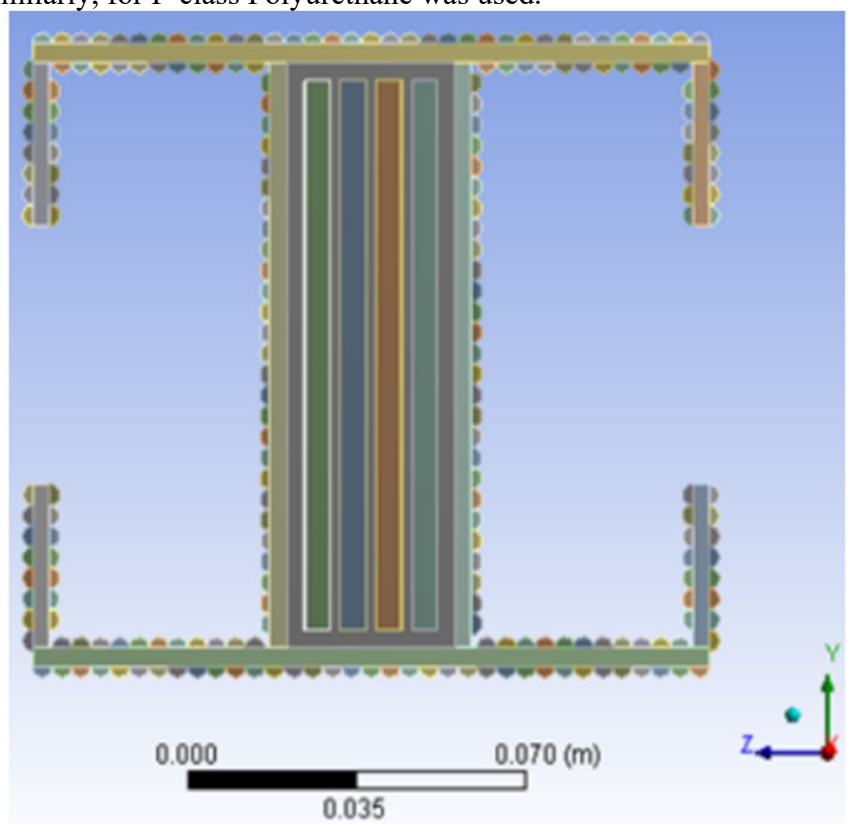

Fig. 2 CAD model of B class insulated busbar 


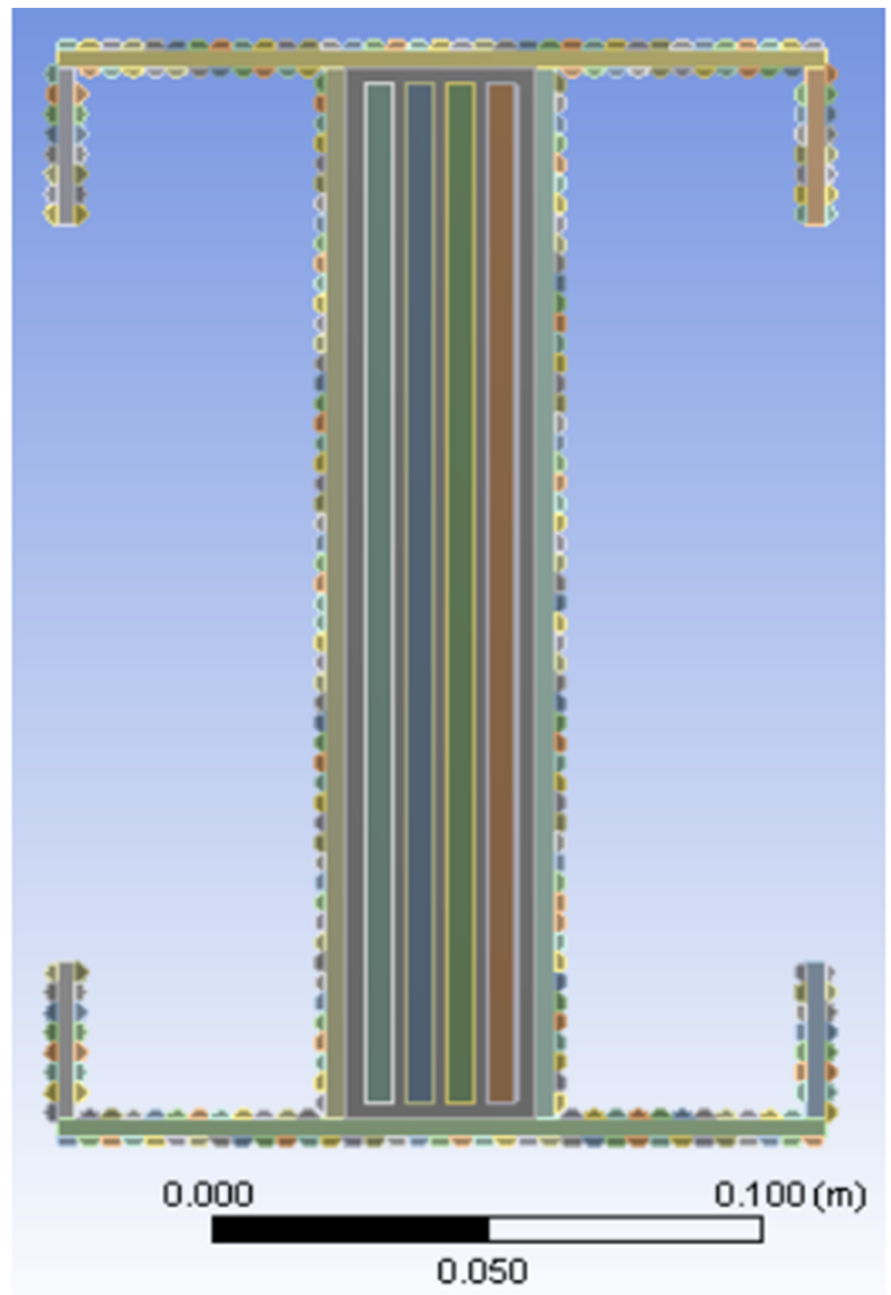

Fig. 3 CAD model of $\mathrm{F}$ class insulated busbar

Table 3 Material properties of the Busbar trunking system

\begin{tabular}{|l|c|c|}
\hline Components & $\begin{array}{c}\text { Electrical } \\
\text { Resistivity }(\mathbf{\Omega} \mathbf{~ m})\end{array}$ & $\begin{array}{c}\text { Thermal conductivity } \\
(\mathbf{W} / \mathbf{m} . \mathbf{K})\end{array}$ \\
\hline Copper & $1.694 \times 10^{-8}$ & 401 \\
\hline Aluminum & $2.67 \times 10^{-8}$ & 144 \\
\hline Tin & $1.1 \mathrm{E}-07$ & 67 \\
\hline B-class insulation & $1 \mathrm{E}+12$ & 0.22 \\
\hline F-class insulation & 10.15 & 0.03 \\
\hline
\end{tabular}

\section{THEORY AND EQUATION}

\subsection{Governing Equations}

This study adopts the numerical analysis using the heat transfer equations, considering conduction and convection as given in equations (1) and (2),

$$
\rho . C_{p} \cdot \mathbf{u} \cdot \nabla T=\nabla \cdot(k \cdot \nabla T)+Q
$$

- n. $(-\mathrm{k} . \nabla \mathrm{T})=\mathrm{h} .\left(\mathrm{T}_{\mathrm{a}}-\mathrm{T}_{\mathrm{s}}\right)$

Where, $\rho$ is the density of the conducting material, $C_{p}$ is the specific heat capacity, $\mathrm{k}$ is thermal conductivity, $\mathrm{h}$ is the heat transfer coefficient. The variables $\mathrm{u}$ and $\mathrm{n}$ denote the velocity vector and normal vector pertaining to the boundary surface. $\mathrm{Q}$ indicates the heat transfer. $\mathrm{T}_{\mathrm{a}}$ and $\mathrm{T}_{\mathrm{s}}$ indicates the temperature of the surrounding atmosphere and the conducting surface respectively (Delgado et al., 2016; Ouyang et al., 2018).

\subsection{Determination of the Convective Heat Transfer}

\section{Coefficients}

The heat flux between the outer surface of the shield maintained at the temperature $T_{a}$ and $T_{s}$ is expressed in the equation (3).

$\mathrm{q}=\mathrm{h}\left(\mathrm{T}_{\mathrm{S}}-\mathrm{T}_{\mathrm{a}}\right)$

The empirical parameter, i.e., heat transfer coefficient is found using the following non-dimensional numbers: Grashoff (Gr), Prandtl (Pr), Rayleigh (Ra) and Nusselt (Nu) (Poddar and Shahshishekar, 2016). Grashof number is expressed by the relation, equation (4):

$\mathrm{Gr}=\frac{\mathrm{g} \beta \Delta \mathrm{TL}^{3}}{\mathrm{~V}^{2}}$

Prandtl number is expressed by the relation shown in equation (5): $\operatorname{Pr}=\frac{\mu \mathrm{C}}{\mathrm{k}}$

Rayleigh number is expressed by the relation shown in equation (6): $R a=\mathrm{Gr} * \mathrm{Pr}$

Nusselt number is expressed by the relation shown in equation (7): $\mathrm{Nu}=\mathrm{aRa}^{\mathrm{b}}$

Where, the constants $a$ and $b$ depend of the characteristics of the system. For this study, $b=0.25$, whereas ' $a$ ' is given below (Bao et al., 2013)

0.27 for the lower parallel surface

0.54 for the upper parallel surface;

0.59 for the perpendicular surfaces;

The Nusselt number is defined by the relation shown in equation (8):

$$
\mathrm{Nu}=\mathrm{h}_{\mathrm{c}} \mathrm{L} / \mathrm{k} \Delta \mathrm{T}
$$

Where $h_{c}$ is the measure of the quantity of heat transferred per unit time per unit area. The thickness of the conducting material ' $\mathrm{L}$ ' is a function of the position of the outside surface $(140 \mathrm{~mm}$ for horizontal surfaces and $217 \mathrm{~mm}$ for vertical surfaces). Table 4 shows the heat transfer coefficient for the busbar systems having the two classes of insulations.

Table 4 Heat transfer coefficient of outer surface

\begin{tabular}{|c|c|c|c|}
\hline Busbar system & $\begin{array}{c}\text { Vertical } \\
\text { surfaces }\end{array}$ & $\begin{array}{c}\text { Vertical } \\
\text { surfaces }\end{array}$ & $\begin{array}{c}\text { Lower } \\
\text { horizontal } \\
\text { surface }\end{array}$ \\
\hline B-class analytical method & 6 & 8 & 2 \\
\hline F-class analytical method & 7 & 9 & 4 \\
\hline B-class numerical method & 6.47 & 8.54 & 2.22 \\
\hline F-class numerical method & 6.97 & 9.30 & 4.65 \\
\hline
\end{tabular}

\subsection{Theoretical Calculation of the Busbar System}

Following parameters are considered for calculating temperature rise of the busbar system. (Barrett, 2013). Heat flow is assumed to be steady state and unidirectional. Following procedures is followed for designing the busbar system:

- Material selection: Polypropylene are used for class-B insulation and Polyurethane are used for the class-F insulation, both of the insulation busbar used with aluminium casing and tin plating

- Design input: for the designing the busbar, the data is collected from the standard catalogue

Calculation of heat transfer in the busbar by the relation shown in equation (9) (Barrett, 2013; Thirumurugaveerakumar et al., 2014). $Q=I^{2} * R$

Where, $\mathrm{I}=2000 \mathrm{~A}$

$\mathrm{R}=$ thermal resistance of the material in $\mathrm{W} / \mathrm{K}$

$R=\frac{\text { Resistivity }(\rho) * \text { Length }(L)}{\text { Area }(A)}$

Calculation of casing temperature by convection is carried out using the equation (10):

$\mathrm{Q}=\mathrm{h} * \mathrm{~A} *(\mathrm{Tc}-\mathrm{T} \infty)$

Where 
$\mathrm{h}=25 \mathrm{~W} / \mathrm{m}^{2} \mathrm{~K}$.

$\mathrm{A}=$ Area in $\mathrm{m}^{2}$

$\mathrm{Tc}=$ Casing Temperature in $\mathrm{K}$.

$\mathrm{T} \infty=$ Initial (or) ambient temperature (assumed $30^{\circ} \mathrm{C}$ )

Calculating Total Heat Transfer inside the Casing is calculated by using equation (11):

$\mathrm{Q}=\mathrm{T}_{\mathrm{d}} / \mathrm{R}_{\mathrm{T}}$

Where

$\mathrm{T}_{\mathrm{d}}=$ Temperature difference $\left(\mathrm{T}_{\mathrm{i}}-\mathrm{T}_{\mathrm{c}}\right)$

$\mathrm{T}_{\mathrm{i}}$ - Inside temperature of the Busbar system

$\mathrm{R}_{\mathrm{T}}=$ Total thermal resistance, calculated by using formula

$\mathrm{R}_{\mathrm{T}}=\mathrm{T} / \mathrm{k} \mathrm{A}$

Number of fins $=\mathrm{Q} / \mathrm{Q}_{\text {fin }}$ is found using the relation shown in equation (12) and (13)

$Q_{f i n}=M \frac{\sinh \left(m_{f i n} L\right)+\left(\frac{h}{m_{f i n} k}\right) \cosh \left(m_{f i n} L\right)}{\cosh \left(m_{f i n} L\right)+\left(\frac{h}{m_{f i n} k}\right) \sinh \left(m_{f i n} L\right)}$
$m_{f i n}=\sqrt{\frac{P * h}{K * A}}$

$\mathrm{M}$ is fin parameter as shown in the equation (14)

$M=\sqrt{h P k A} *\left(T_{a}-T_{c}\right)$

To find the temperature distribution on fin (Tx) as shown in the equation (15)

$\frac{T_{x}-T_{\infty}}{T_{c}-30}=\frac{\cosh (L-x)+\left(\frac{h}{m k}\right) \sinh m(L-x)}{\cosh (m l)+\left(\frac{h}{m k}\right) \sinh m l}$

$\mathrm{T}_{\mathrm{x}}=326.64 \mathrm{~K}$ at the tip of the fins (F-class insulation busbar)

The above fin design methodologies are used to obtain the same fin tip temperature by assuming variable parameters are Width, thickness and current rating of the fin. Conduction and convection method is used to find out the temperature of the busbar system casing by numerical method is presented in Table 5. Calculation is carried out on each portion of the busbar such as conductor, insulator, casing and fins (Yingsan, 2003).

Table 5 Numerical values of temperature rise $\left({ }^{\circ} \mathrm{C}\right)$

\begin{tabular}{|l|c|c|}
\hline Components & $\begin{array}{c}\text { Temperature for } \\
\text { F-Class insulation }\end{array}$ & $\begin{array}{c}\text { Temperature for } \\
\text { B-Class insulation }\end{array}$ \\
\hline Copper conductor & 152.914 & 127.281 \\
\hline Neutral conductor & 108.214 & 106.771 \\
\hline Insulator & 152.882 & 127.292 \\
\hline Casing & 59.181 & 88.683 \\
\hline Fins & 53.643 & 80.052 \\
\hline
\end{tabular}

\section{RESULT AND DISCUSSIONS}

For considering the two classes (B-class \& F-class) of insulation for the compact sandwich busbar arrangement as per table 1, material properties in table2, and coefficient of heat transfer for vertical and horizontal surface in table 3 as well as boundary condition as denoted in section III. The finite elemental analysis of three-dimensional three phase busbar/ with different classes of insulation with same geometry of busbar system and it is solved by ANSYS 15.0. Fig. 4 represents the B-class insulating material with AL casing, current 2000A induced in the copper conductor of the sandwich busbar system.

The conductors are provided with a 3-phase electrical supply in one of its side, while the other sides of the busbar are subjected to short circuit. For considering the B class insulation of copper conductor with AL casing. Considering the $\mathrm{B}$ classes material property, insulation will withstand the temperature up to $130^{\circ} \mathrm{C}$. Fig. 3 represents the temperature distribution of AL casing with copper conductor. The conductor will reach the maximum operating temperature of $129.61^{\circ} \mathrm{C}$ with including the ambient temperature of $35^{\circ} \mathrm{C}$ (Hedia et al., 1999). The geometry is designed in such a way that the design follows the IEC guidelines of temperature limits at the casing also i.e., the maximum operating temperature for the design at the casing $90^{\circ} \mathrm{C}$ which include the ambient temperature of $35^{\circ} \mathrm{C}$. The insulation material is placed in between the copper conductors.

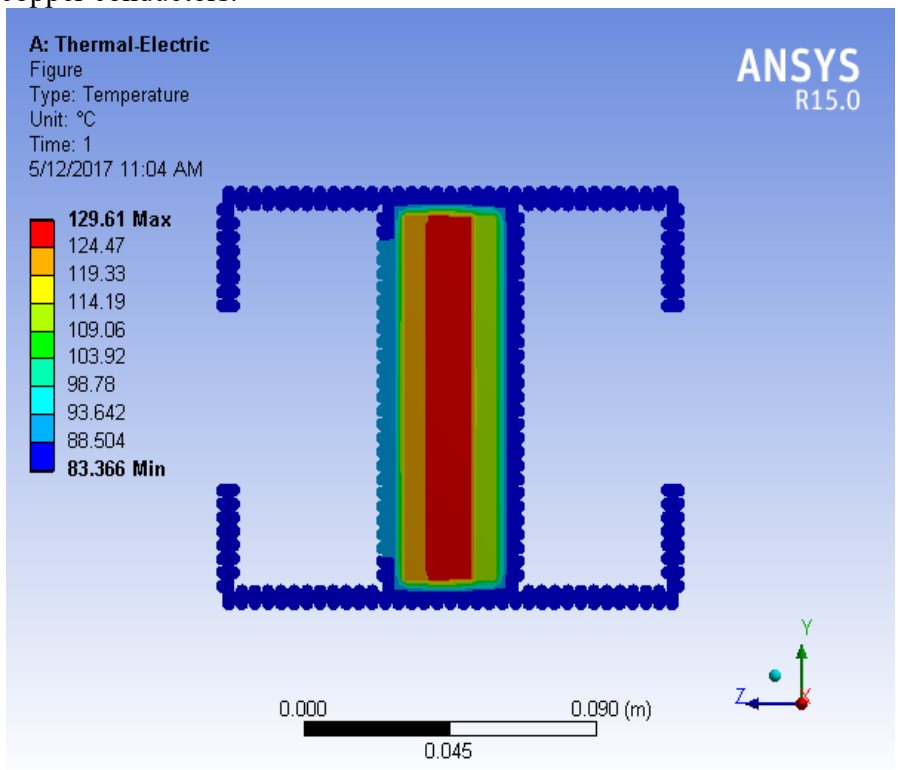

Fig. 4 Temperature distribution of B-class insulation busbar arrangements

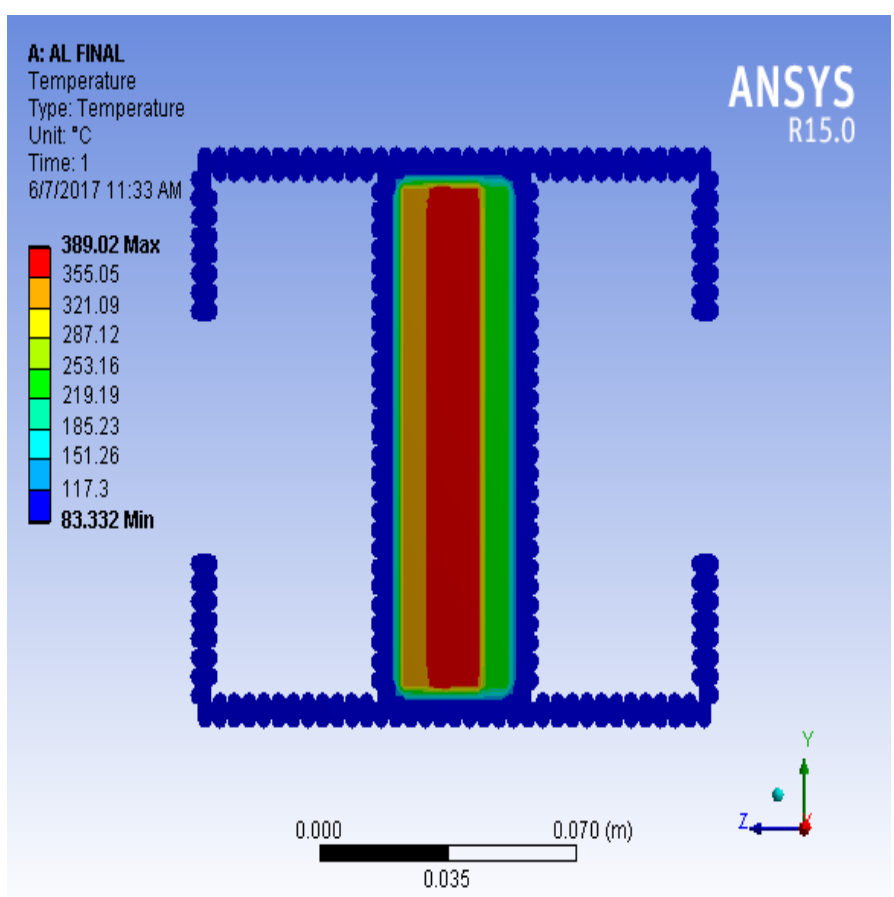

Fig. 5 Temperature distribution of F-class insulation with B-class busbar geometry

The size of copper conductor with the final temperature limits of $90^{\circ} \mathrm{C}$ at casing and $129.5^{\circ} \mathrm{C}$ at the conductor is $5.37 \mathrm{~mm} \times 105.6 \mathrm{~mm}$. Outer side of the aluminium casing convection process will be applied of $6.87 \mathrm{Wm}^{-2} \mathrm{C}^{1}$. Further increase in the temperature shall be beyond the threshold limit of the class $\mathrm{B}$ insulation. As per the numerical analysis of B-Class insulation busbar geometry will damage while replacing the Bclass to F-class insulation. The temperature variation by replacing the class of insulation from Class B to Class F with the same geometry is also shown in Fig. 5. The replacement of polypropylene (Class B) to polyurethane (Class F) makes the insulation with a good thermal endurance to resist the temperature with in the insulation domain.

Due to effect of changing the class of insulation, the temperature at the conductor gets increase up to $390^{\circ} \mathrm{C}$ including ambient temperature 
of $35^{\circ} \mathrm{C}$. However, the aluminium casing will remain below $90^{\circ} \mathrm{C}$ because of insulation medium acting in-between the conductor and its casing. As the class of insulation is only F-class insulation material property which can withstand the maximum operating temperature of $155^{\circ} \mathrm{C}$. However, Fig. 5 shows the maximum operating temperature of $390^{\circ} \mathrm{C}$ which is beyond the F-class insulation limit. In order to compensate the required temperature, the copper conductor is increased resulting in reduction of heat generation and the conductor is increased till the final temperature is attained to $155^{\circ} \mathrm{C}$. The copper conductor size is increased to $5.2 \mathrm{~mm} \times 203 \mathrm{~mm}$ with same insulation thickness is interface between the conductors.

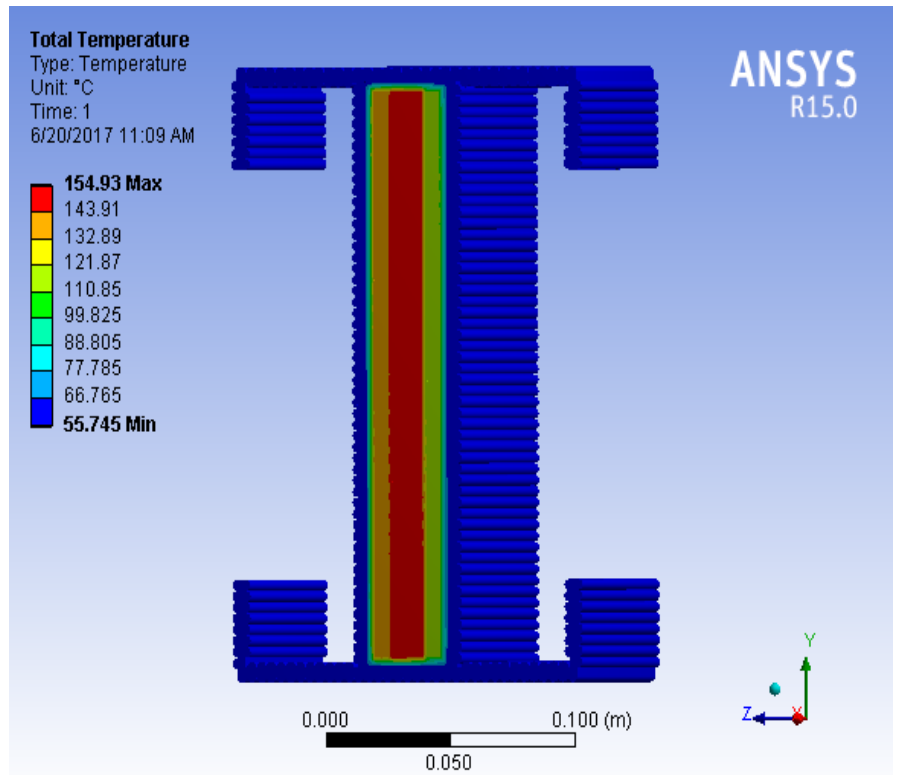

Fig. 6 Temperature distribution of F-class insulation busbar arrangements

As per the thermal electric analysis of F-class insulating with aluminium casing busbar analysis of temperature distribution are shown in Fig. 6. The conductor will reach the maximum operating temperature of $154.93^{\circ} \mathrm{C}$ including the ambient temperature of $35^{\circ} \mathrm{C}$. Convection boundary condition are acting over the aluminium casing of the busbar geometry.

Fig. 7 shows the temperature distribution within the enclosure of the F-class insulation with compact busbar arrangements. It can be observed that the peak temperature occurs along the side plates over the enclosure. Fig. 7 shows the temperature at casing is $60.5^{\circ} \mathrm{C}$ including ambient temperature $35^{\circ} \mathrm{C}$, wherein the temperature at the casing for the class $\mathrm{B}$ insulation was $90^{\circ} \mathrm{C}$. The hot spot temperature will be attaining at the center side wall of the busbar casing because of the copper conductor temperature will be transmit towards the enclosure, the polyurethane insulation will used to reduce the thermal distribution to the aluminium casing.

Fig. 8 shows the effect of the F class insulation thickness on the temperature rise of busbar. In this study, the insulation thickness is increased from 0.5 to $2.1 \mathrm{~mm}$. It can be observed that the increase in the temperature of the busbar is proportional to the material thickness of the insulation. The temperature rise within the enclosures is prevented by polyurethane insulation. $2 \mathrm{~mm}$ thickness of the insulation is chosen based on the factors that affect its thermal and electric behavior. The F-class insulation material maximum temperature of $\mathrm{Al}$ casing system is $154.93^{\circ} \mathrm{C}$ to minimum at $60.53^{\circ} \mathrm{C}$. The B-class system provided 6 times increase in the convective heat transfer comparing the readings from the vertical surfaces and horizontal surface. However, the heat transfer in the vertical surfaces in the case of F-class insulation was only 3.52 times greater than that of the horizontal surface in the busbar system.

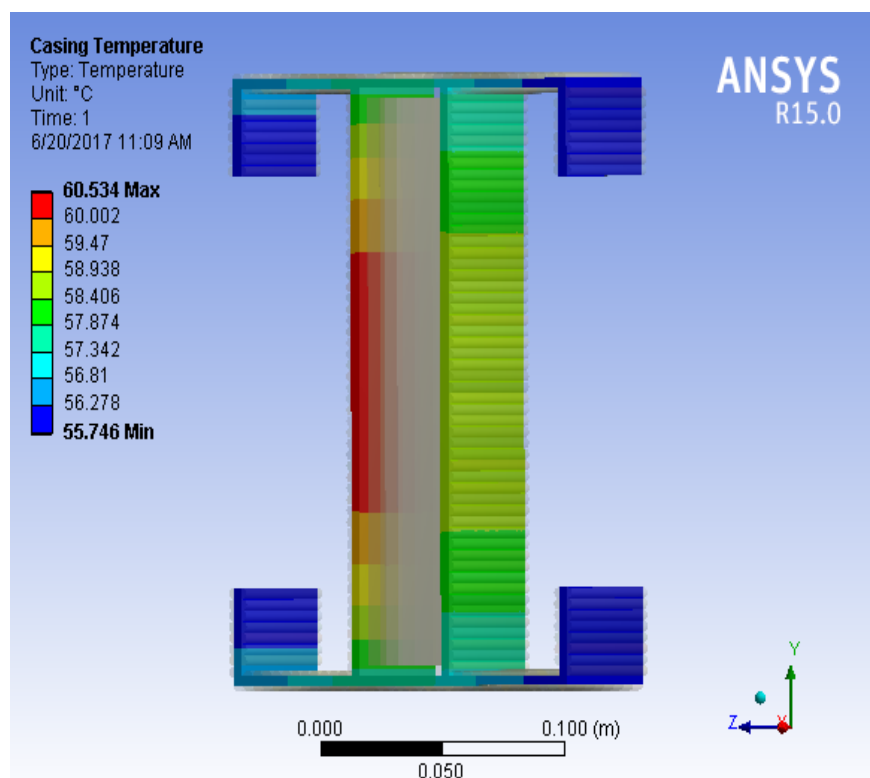

Fig. 7 Temperature distribution of AL casing of F-class insulation busbar arrangements

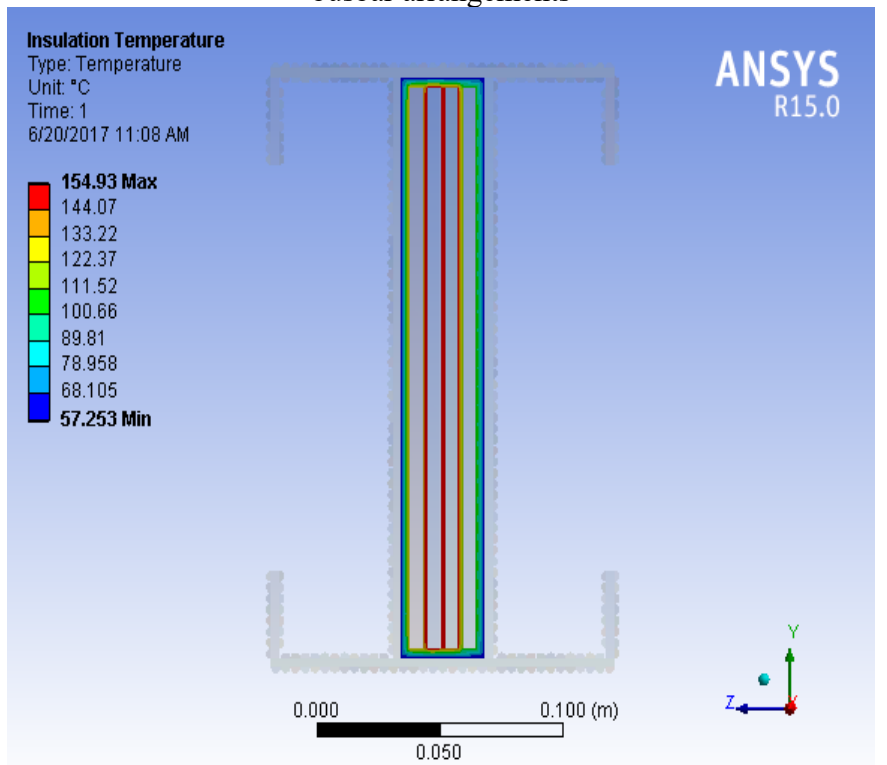

Fig. 8 Thermal distribution of F class Insulation with AL casing sandwich busbar Assembly

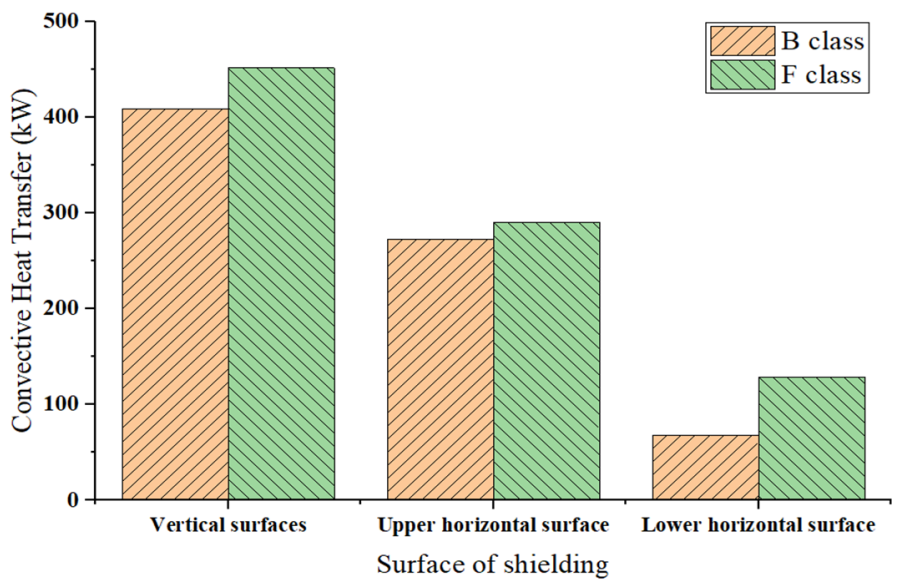

Fig. 9 Convective heat transfer in B-class and F-class insulated busbar system 
The vertical surfaces allowed better heat transfer than the horizontal surfaces irrespective of the insulation class used in the busbar system. In the case of the B-class insulation, the upper horizontal surface allowed 4 times greater convective heat transfer than the lower horizontal surface. While the upper horizontal surface provided only 2.26 times increase in the convective heat transfer than the lower horizontal surface in the case of F-class insulation in the busbar system. Though the convective heat transfer in the B-class insulation is greater in the vertical surfaces than the lower horizontal surface, the F-class insulated outperformed the Bclass insulation by providing increased convective heat transfer to the surrounding. This is justified by comparing the heat transfer in the lower horizontal surface of the two different insulation classes used in this study. It is observed that the lower horizontal surface in the F-class insulation is 1.88 times greater than that of the B-class insulated busbar system as shown in the Fig. 9.

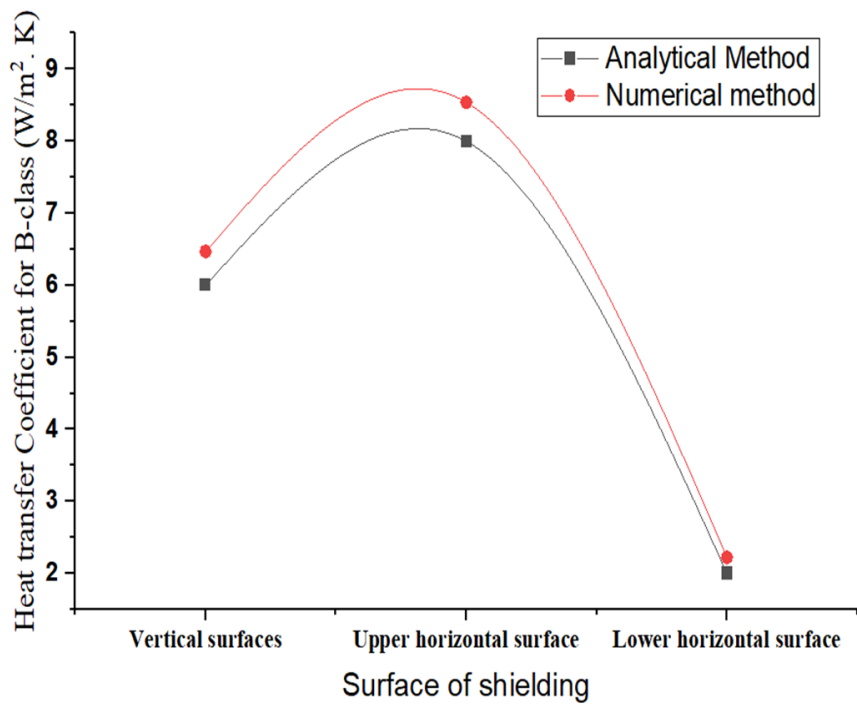

a. Heat transfer coefficient for B-class insulation

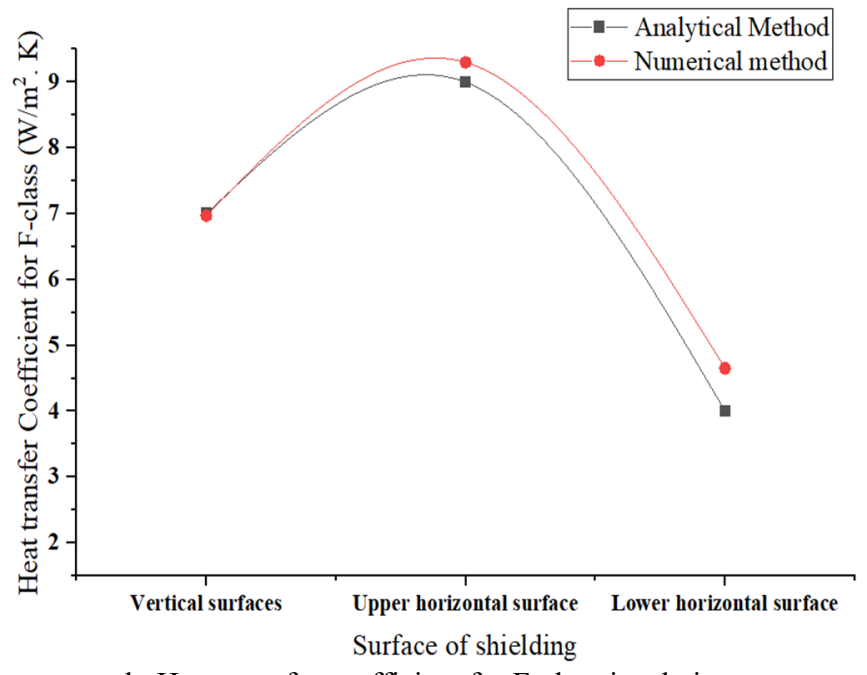

b. Heat transfer coefficient for F-class insulation

Fig. 10 Comparison of the Analytical and Numerical results of the heat transfer coefficient

Numerical results are obtained from standard theoretical equation which shown above are compared with computed results from ANSYS 15.0. Fig. 10 shows the heat transfer coefficient calculated through the theoretical equation and numerical approach for the two different insulation classes considered for this study. The results obtained through the numerical approach correlated closely with the results obtained through the theoretical approach irrespective of the insulation class. Table 6 and Table 7 shows the temperature raise in the various components in the busbar systems considered for this study.
Table 6 Numerical and computed results of temperature rise $\left({ }^{\circ} \mathrm{C}\right)$ for BClass Insulation

\begin{tabular}{|l|c|c|c|}
\hline \multirow{2}{*}{$\begin{array}{l}\text { Measured } \\
\text { region } \\
\text { component }\end{array}$} & \multicolumn{3}{|c|}{ Temperature for B-class insulation Al casing } \\
\cline { 2 - 4 } & Theoretical & Computed & Error \% \\
\hline Conductor & 127.281 & 129.61 & 1.79 \\
\hline Neutral & 106.771 & 110.56 & 3.43 \\
\hline Insulator & 127.292 & 129.59 & 1.77 \\
\hline Casing & 88.683 & 90.444 & 1.95 \\
\hline Fins & 80.052 & 83.366 & 3.97 \\
\hline
\end{tabular}

Table 7 Numerical and computed results of temperature rise $\left({ }^{\circ} \mathrm{C}\right)$ for $\mathrm{F}$ Class Insulation

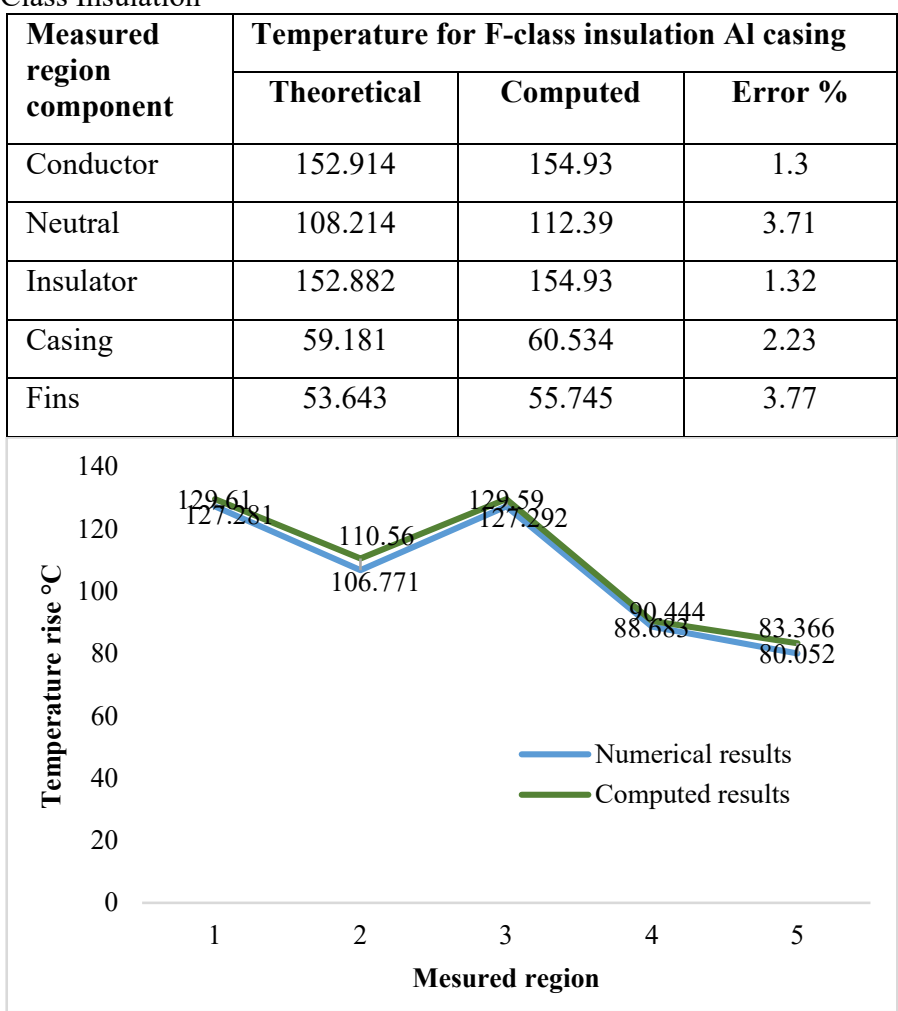

a. Temperature rise for B-class insulation

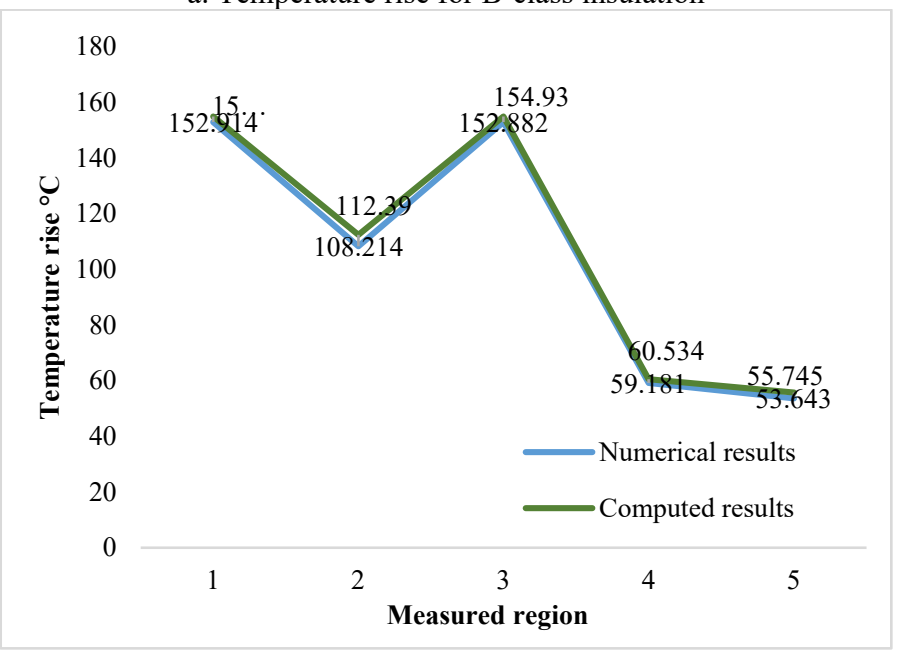

b. Temperature rise for F-class insulation

Fig. 11 Comparison of the Analytical and Numerical results of the Temperature raise 
The results show the variation of the busbar temperature in $\mathrm{B}$ and $\mathrm{F}$ class insulation. The temperature in the conductor and the insulator are maintained same, indicating that the conductive heat transfer was optimal irrespective of the type of insulation provided in the busbar system. However, the neutral had 28\% lower temperature than the insulator in the F-class insulated busbar system. In the case of the B-class insulated busbar system, the neutral had $16.5 \%$ lower temperature than the insulator. The casing and the fins in both the busbar system are maintained temperature below $100^{\circ} \mathrm{C}$ irrespective of the insulation class.

Interestingly, the F-class insulation indicated $29.5^{\circ} \mathrm{C}$ and $26.4^{\circ} \mathrm{C}$ lower temperature than the B-class insulation in the casing and the fins respectively. This infers that the heat transfer did not carry over to the casing, while the lower temperature in the fins enhanced convective heat transfer in the busbar system having F-class insulation. The temperature rise attained by numerical and analytical values by varying temperatures are plotted in Fig. 11. The reasonable error of $1.32 \%$ in the F-class insulation containing $\mathrm{Al}$ casing in the busbar system depicts good accuracy in the result. It is inferred that the F-class insulation permitted increased heat transfer because of the high temperature in its components.

\section{CONCLUSIONS}

A thermal model of a short circuit three-phase compact busbar assembly is established using ANSYS 15.0 to determine the influence of B-class and F-class insulations on the maximum temperature limit. The results are validated using theoretical results and numerical models according to IEC temperature limits. Factors such as temperature rises in busbar and its enclosure and also the heat transfer coefficient of horizontal and vertical surfaces were determined using thermal equations. The following conclusions are given based on the results obtained from the study:

- Changing the class of insulation from B class to F class leads to raise in the conductor temperature while simultaneously reducing the casing temperature. This effect is observed while changing the size of the busbar.

- Class B insulation in the busbar duct allow greater current density of $3.52 \mathrm{~A} / \mathrm{m}^{2}$ while the Class $\mathrm{F}$ insulation allow only $1.89 \mathrm{~A} / \mathrm{m}^{2}$ current density.

- F class insulation having copper conductor and aluminium casing develops less heat dissipation through the enclosure and lower power loss compared to the B class insulation.

- Convective heat transfer in the F-class insulated busbar system is superior than its counterpart having B-class insulation.

- Both the Theoretical results and numerical model show that Fclass insulation outperformed the B-class insulation by exhibiting increased heat transfer coefficient and temperature through the enclosure.

- The calculated and analysis results show good agreement with minimum error percentage.

\section{NOMENCLATURE}

\section{Symbol Description}

$\mathrm{A}_{\mathrm{s}} \quad$ Surface area $\left(\mathrm{m}^{2}\right)$

$\mathrm{C}_{\mathrm{p}} \quad$ Specific heat at constant pressure $(\mathrm{kJ} / \mathrm{kg} . \mathrm{K})$

$\mathrm{G} \quad$ Acceleration due to gravity $\left(\mathrm{m} / \mathrm{s}^{2}\right)$

Gr Grashoff number

$\mathrm{h} \quad$ Convective heat transfer coefficient $\left(\mathrm{W} / \mathrm{m}^{2} . \mathrm{K}\right)$

I Current (A)

$\mathrm{k} \quad$ Thermal conductivity of air (W/ m.K)

$\mathrm{Nu} \quad$ Nusselt number

$\mathrm{P} \quad$ Perimeter of the fin $(\mathrm{m})$

Pr Prandtl number

Q Heat transfer (W)

q Heat flux $\left(\mathrm{W} / \mathrm{m}^{2}\right)$

$\mathrm{Ra} \quad$ Rayleigh number

\author{
$\mathrm{R}(\mathrm{t}) \quad$ A.C. Electric resistance as a function of \\ temperature $(\Omega)$ \\ $\mathrm{T}_{\max } \quad$ Maximum operating temperature $\left(\mathrm{K},{ }^{\circ} \mathrm{C}\right)$ \\ $\mathrm{T} \quad$ Ambient air temperature $\left(\mathrm{K},{ }^{\circ} \mathrm{C}\right)$ \\ $\mathrm{t} \quad$ Thickness $(\mathrm{m})$ \\ $\Delta \mathrm{T} \quad$ Temperature difference $\left(\mathrm{K},{ }^{\circ} \mathrm{C}\right)$ \\ $\mathrm{L} \quad$ Representative linear dimension $\mathrm{m}$ \\ V Kinematic viscosity $\left(\mathrm{m}^{2} / \mathrm{s}\right)$ \\ C Heat capacity at constant pressure (J/kg. K) \\ Greek Symbols \\ $\beta \quad$ Coefficient of thermal expansion \\ $\mu \quad$ Dynamic viscosity (Pa.s) \\ $\varepsilon \quad$ Emissivity \\ $\rho \quad$ Density $\left(\mathrm{g} / \mathrm{m}^{3}\right)$ \\ $\sigma \quad$ Stefan-Boltzmann constant $\left(\mathrm{W} / \mathrm{m}^{2} \mathrm{~K}^{4}\right)$
}

\section{REFERENCES}

Anbo, W., Degui, C., Jianhua, W., Bin, C., and Yingsan, G., 2002, "Evaluation of Thermal Performance for Air-Insulated Busbar Trunking System by Coupled Magneto-Fluid-Thermal Fields," Proceedings. Power Conf. 2002, 4, 2159-2163. https://doi.org/10.1109/ICPST.2002.1047164

Bao, Y.J., Cheng, K.W.E., Ding, K., and Wang, D.H., 2013, "The study on the busbar system and its fault analysis" $5^{\text {th }}$ International Conference on Power Electronics Systems and Applications, 21-24. https://doi.org/10.1109/PESA.2013.6828246

Barrett, R., 2013, “Operating Temperature of Current Carrying Copper Busbar Conductors," A Dissertation.

Burali, Y.N., and Patil, M.B., 2014, "Paper in Busbar Trunking System for Electrical Supply to Industrial and Commercial Insulation," IOSR Journal of Engineering, 4(1), 1-12.

Delgado, F., Renedo, C., Ortiz, A., and Fernández, I., 2016, "Numerical Model of a Three-Phase Busbar Trunking System" IEEE Electrical Insulation Conference, 21-24. https://doi.org/10.1109/EIC.2016.7548584

Guzman, A., Qin, B.L., and Labuschagne, C., 2005, "Reliable Busbar Protection with Advanced Zone Selection," IEEE Transactions on Power Delivery, 20(2), 625-629.

https://doi.org/10.1109/TPWRD.2004.834671

Hedia, H., Henrotte, F., Meys, B., Dular, P., Legros, W., and Pirotte, P., 1999, "Arrangement of Phases and Heating Constraints in a Busbar," IEEE Transactions on Magnetics, 35(3), 1274-1277.

https://doi.org/10.1109/20.767183

Ho, S. L., Li, Y., Lin, X., Wong, H.C.C., and Cheng, K.W.E., 2006, “A 3-D Study of Eddy Current Field and Temperature Rises in a Compact Bus Duct System," IEEE Transactions on Magnetics, 42(4), 987-990. https://doi.org/10.1109/TMAG.2006.871632

IEC 61439-1, Low-Voltage Switchgear and Control Gear Assemblies, General Rules

IEC 61439-1, Low-Voltage Switchgear and Control Gear Assemblies, Busbar Trunking Systems

Kevin W.I., Sally M.S., Andrew, D.W., Derek W.H., and Joy M.S., 2019, "Long-Term On-Orbit Thermal Performance of Aerogel Insulation" Frontiers in Heat and Mass Transfer, 12-30. https://doi.org/10.5098/HMT.12.30

Manna, R., and Oosthuizen, P.H., 2019 "Numerical and Experimental Investigations of Natural Convective Heat Transfer from Two-Sided Diagonally Inclined Square Plates Having a Finite Thickness," Frontiers in Heat and Mass Transfer, 13-17.

https://doi.org/http://dx.doi.org/10.5098/hmt.13.7 
Mohan. S.M., and Chatterjee, S., 2010, "Busbar Protection - A Review," $8^{\text {th }}$ International Conference on Computational Technologies in Electricals and Electronics Engineering, 112-123. https://doi.org/10.1109/SIBIRCON.2010.5555158

Ohta, S., 1985, "Temperature Classes of Electrical Insulators," Three Bond Technical News, 13.

Ouyang, Z.B., Zhnag, G.Q., Hou, Z., Wang, G.Z., Li, H.B., Zheng, Z.Q., Shao, B.Z., and Yu, T.W., 2018, "Summarization of Busbar Protection Principle," IOP Conference Series: Earth and Environmental Science, 113, $1-10$.

https://doi.org/10.1088/1755-1315/113/1/012105

Poddar, P., and Shashishekar, D., 2016, "Thermal Analysis of Sandwich Busbar System". International Journal of Science, Engineering and Technology, 711-714.

https://doi.org/10.2348/ijset06150711

Rosch, S.J., 1938, "The Current-Carrying Capacity of Rubber-Insulated Conductors," Electrical Engineering, 57(3), 155-167.

https://doi.org/10.1109/EE.1938.6431188

Thirumurugaveerakumar, S., Sakthivel, M., and Valarmathi, S., 2014, "Experimental and Analytical Study on the Bus Duct System for the Prediction of Temperature Variations Due to the Fluctuation of Load,"
Journal of Electrical Engineering and Technology, 9(6), 2036-2041. https://doi.org/10.5370/JEET.2014.9.6.2036

Viswanatha, C., and Rakesh, K.G., 2016, "Investigation of Epoxy Coated Busbar System Enclosed in LT Busduct of Rating 2000A," $\sigma^{\text {th }}$ International Conference on Power Systems, 1-5. https://doi.org/10.1109/ICPES.2016.7584207

Wang, H.D., and Guo, Z.Y., 2019, "Physical Heat Transfer," Frontiers in Heat and Mass Transfer, 13-20.

https://doi.org/http://dx.doi.org/10.5098/hmt.13.20

Xu, X., Li, H., and Wen, H., 2015, "Performance Evaluation of Busbar Protection Schemes Under Different Fault Scenarios," $9^{\text {th }}$ International Conference Power Electronics and ECCE, 1597-1602. https://doi.org/10.1109/ICPE.2015.7167990

Tian, Y., and Zhao, M., 2019, "Thermal Analysis of Heat Transfer Enhancement of Rib Heat Sink for CPU," Frontiers in Heat and Mass Transfer, 13-4.

https://doi.org/10.5098/HMT.13.4

Yingsan, G.A., 2003, "Finite Element Analysis of Coupled MagnetoThermal Fields for Compact Busbar Trunking System," High Voltage Apparatus, 39(4), 7-10. 